УДК 811.111-13:81'34:37.091.33:165.194

\title{
РОЗВИТОК КОГНІТИВНИХ ЗДІБНОСТЕЙ УЧНІВ НА УРОКАХ АНГЛІЙСЬКОЇ МОВИ ЗАСОБОМ ГРИ СЛІВ “КАЛАМБУР”
}

\author{
Красуля А. В., Гончарова О. В. \\ a.krasulia@gf.sumdu.edu.ua, 11o.goncharova@gmail.com \\ https://orcid.org/0000-0003-2048-1879 https://orcid.org/0000-0002-5178-3784 \\ Сумський державний університет
}

Дата надходження 02.06.2020. Рекомендовано до друку 24.06.2020.

\begin{abstract}
Анотація. У статті окреслено важливість розвитку когнітивних здібностей на уроках англійської мови 3 метою формування лінгвістичної компетентності учнів. Дослідження, метою якого є пошук нових технологій формування пізнавальних здібностей, виконано на основі положень теорії когнітивного розвитку людини. Розглянуто взаємозв'язок процесу опанування іноземної мови та когнітивних навичок. Наголошується на доцільності впровадження в навчання ігрової діяльності заради всебічного пізнання іншомовної культури. У статті розглядаються прояви гри у парадигмі лінгвістики, психолінгвістики, когнітивної психології та методики навчання іноземних мов (“мовна гра”, “гра слів”, “каламбур”). Представлено різні варіації використання гри слів на уроках англійської з метою розвитку пізнавальних здібностей, лексичних і фонологічних навичок учнів, а також формування в них соціолінгвістичної компетентності.
\end{abstract}

Ключові слова: когнітивні здібності, мовна гра, гра слів, каламбур, соціолінгвістична компетентність.

Красуля А. В. Гончарова О. В. Сумской государственный университет

Развитие когнитивных способностей учащихся на уроках английского языка посредством игры слов “каламбур"

Аннотация. В статье раскрыта важность развития когнитивных способностей на уроках английского языка с целью формирования лингвистической компетентности учащихся. Исследование, целью которого является поиск новых технологий формирования познавательных способностей, выполнено на основе положений теории когнитивного развития человека. Рассмотрена взаимосвязь процесса овладения иностранным языком и развития когнитивных навыков. Отмечается целесообразность использования игровой деятельности на уроках английского языка для всестороннего изучения иноязычной культуры. В статье рассматриваются проявления игры в парадигме лингвистики, психолингвистики, когнитивной психологии и методики обучения иностранным языкам (“языковая игра”, “игра слов”, “каламбур”). Представлены различные варианты использования игры слов на уроках английского языка с целью развития познавательных способностей, лексических и фонологических навыков учащихся, а также формирования у них социолингвистической компетентности.

Ключевые слова: когнитивные способности, языковая игра, игра слов, каламбур, социолингвистическая компетентность.

Krasulia A., Honcharova O. Sumy State University

Development of Students' Cognitive Abilities by Means of a Wordplay "Pun" in English Classes

Abstract. Introduction. English, as a language of international communication, is a key to great opportunities for a successful life and work in the modern world. The main purpose of the English language learning is to develop high linguistic awareness from an early age. As a result, foreign language teachers face up to the problem of finding engaging and effective ways for students' all-round development. Purpose. The article outlines the need to develop students' cognitive abilities to perceive and communicate in a foreign language. The aim of our research is to find new teaching methods that could foster the development of cognitive abilities including perception, memory, problem-solving skills, logics, and imagination via a wordplay "Pun". Methods. The study provides theoretical analysis and synthesis of an array of resources related to the cognitive component of English as a foreign language (EFL) learning and the phenomenon of a language game. The research utilizes a sampling method for the selection of examples for the wordplay "Pun" implementation in class, and describes its varieties in the English language 
discourse. Results. The article gives an overview of the essence of cognitive skills during the EFL acquisition. The study supports the importance of game activities for comprehensive cognition. As foreign language learning builds up knowledge about the world where this very language is used, the article discusses all the manifestations of the concept 'game' in the linguistics and EFL teaching / learning paradigm. The study covers different variations of wordplay aimed at developing cognitive abilities, especially students' lexical and phonological skills, as well as raising their linguistic awareness. Conclusion. The authors came up with a conclusion that the implementation of a wordplay, namely pun, is one of the most appropriate ways for students' cognitive abilities development in an EFL classroom.

Key words: cognitive abilities, language game, wordplay, pun, sociolinguistic competence.

Постановка проблеми. У сучасному світі життя людини як ніколи пов'язане з міжкультурним спілкуванням. Навчання, пошук інформації, працевлаштування, подорожі постійно вимагають високого рівня володіння іноземними мовами. Особливу роль відіграє вивчення англійської найголовнішої мови міжнародної комунікації. За таких обставин вимоги до рівня мовної підготовки учнів у закладах середньої освіти (3СО) зростають. Наразі завдання вчителя не просто передати знання, а сформувати розвинену особистість, відкриту й готову до використання англійської мови як засобу міжкультурної мовленнєвої взаємодії. Для того, аби отримати бажаний результат, учням необхідно мати достатню практику у використанні іноземної мови, сприймати іiі та самостійно продукувати іншомовний матеріал. Окрім того, велике значення має розвиток когнітивних здібностей (мислення) під час спілкування іноземною мовою та цілеспрямоване формування іншомовної лінгвістичної (мовної) компетентності. При цьому з боку вчителя важливо подбати про подолання учнями психологічної скутості під час іншомовного спілкування.

Актуальність дослідження визначається нагальною потребою пошуку нових технологій розвитку комунікативних і когнітивних здібностей у процесі вивчення іноземної мови. Саме вони є головними у сучасній парадигмі наукового знання, оскільки поєднують оволодіння мовленнєвою діяльністю та пізнання мови.

Ураховуючи сучасні тенденції навчання іноземних мов, важливо, аби технології формування іншомовної компетентності були доцільними для учнів, викликали інтерес до вивчення. Крім того, метою розвитку соціолінгвістичної компетентності має бути не лише практичне опанування мовної системи, а й розуміння культури країни та її мовців.

Аналіз останніх досліджень і публікацій. В основі теоретичних засад про когнітивні здібності людини лежать наукові доробки Ж. Піаже (1967). Психолінгвістичні дослідження ролі когнітивних навичок у процесі вивчення іноземної мови представлено в роботах Дж. Брунера й У. Ріверса. Положення когнітивної теорії навчання визначено на основі досліджень Н.М. Гудкової (2015). Явище мовної гри було окреслено, спираючись на дослідження Л. Вітгенштайна (1995). Зокрема, в методиці навчання іноземних мов дослідженням особливостей формування комунікативно-навчальних умінь проведення буквених ігор займалася В.М. Карпова (1995). Розгляду когнітивного підгрунтя мовленнєвих навичок присвячено дослідження Ю.В. Якимчука (2010). Питання розвитку ідіоматичності іншомовного мовлення, як важливої умови ефективності мовленнєвого спілкування, розглядається Г.І.Подосинніковою (2002). Методологічні положення щодо формування мовних і мовленнєвих компетентностей викладено у наукових розвідках вітчизняних дослідників (О.Б. Бігич (2013), О.І. Вовк (2013), С.Ю. Ніколаєвої (2010).

Мета статті полягає у висвітленні способів застосування гри слів “каламбур” на уроках англійської мови з метою розвитку когнітивних здібностей учнів. Низка дослідницьких завдань відповідає поставленій меті й охоплює розгляд таких питань: 1) визначення поняття когнітивних здібностей та обгрунтування важливості їх розвитку під час вивчення іноземної мови; 2) аналіз явища мовної гри та його різновиду гри слів “каламбур”; 3 ) пошук технологій упровадження гри слів як методичного матеріалу на уроках англійської мови. 
Основні результати дослідження. В основі формування високої мовленнєвої компетентності учнів лежить розвиток їхніх когнітивних здібностей (англ. cognitive “пов'язаний з ментальними процесами розуміння"). До таких розумових процесів належать сприйняття, пам'ять, вирішення завдань, діяльність, пов'язана з логікою та уявою. Вони допомагають людині обробляти інформацію, отриману із зовнішнього світу. Когнітивні здібності $\epsilon$ частково вродженими, основну їх частину вважають такими, що розвиваються та набуваються в процесі життя.

Відповідно до концептуальних засад когнітивної психології, зокрема когнітивної теорії розвитку Ж. Піаже (1967), існують кілька стадій розвитку людини, на яких формуються нові пізнавальні навички. Принагідно зауважимо, що на кожній стадії розвитку людині можна закласти лише властиві певному етапу знання. Пізніше, на основі когнітивної психології, було створено когнітивну теорію навчання іноземних мов - когнітивний підхід авторів Дж. Брунера й У. Ріверс. Основна мета всіх методів у межах цього підходу полягає у розвитку інтелекту, тобто усіх розумових здібностей і стратегій, що уможливлюють процес навчання й адаптації до нових умов.

Когнітивна теорія навчання грунтується на таких положеннях:

1) розвиток мислення є невід'ємною складовою процесу оволодіння мовою; навчання мови не повинно будуватися лише на сприйнятті та механічному заучуванні одиниць мови або граматичних правил; учнів доцільно залучати до активного процесу пізнання суті явищ, створювати умови для реалізації особистісних орієнтирів;

2) учні мають бути активними учасниками процесу навчання, під час якого необхідно враховувати їхні індивідуальні інтереси й особливості;

3) процес навчання має носити соціально обумовлений характер - як учні, так і вчителі мають бути залучені до процесу взаємного пізнання і розуміння один одного та співробітництва під час навчання й учіння (Гудкова, 2015).

Ж. Піаже (1967) відзначав, що необхідним елементом для нормального інтелектуального розвитку людини $\epsilon$ гра. Іграм завжди відводиться значна частина активності дитини, вони $\epsilon$ способом дослідження навколишнього світу - людей, явищ, предметів: “Гра - це місток між конкретним досвідом дитини й абстрактним мисленням, у зв'язку із цим найважливішою функцією гри є іiі символічний характер. У грі діти організовують свій досвід. Вона надає конкретну форму і вираз внутрішнього світу дитини" (Піаже, 1967, с. 53).

Помилковим буде вважати, що впровадження гри для формування когнітивних навичок ефективне лише у ранньому віці. Принагідно зауважимо, що гра - це серйозна розумова діяльність, яка здатна розвивати всі види здібностей людини. Елементи гри під час вивчення мови у будь-якому віці сприяють створенню стійкіших асоціативних зв'язків порівняно зі звичайним навмисним запам'ятовуванням. Ігрова діяльність дає учасникам змогу проявити себе, навчитися активно користуватися вивченим матеріалом, окрім того учень підсвідомо знаходить найкращий спосіб запам'ятовування (чи то шляхом багаторазового повторення, чи вибудовуванням асоціацій, аналізу перебігу гри, наслідування тощо).

У парадигмі лінгвістики та навчання мов поняття “гри” не $\epsilon$ однозначним. Терміни мовна гра, гра слів, каламбур переплітаються, вживаються поруч, часом помилково та створюють враження, ніби позначають одне і те саме поняття. Насправді ж кожен з наведених термінів ілюструе унікальне явище, яке існує на перетині мовознавства, лінгвокультурології, психолінгвістики, когнітивної психології та знайшло своє відображення у методиці навчання іноземним мовам.

Найширшим за своїм змістом $є$ поняття мовної гри, яке започаткував австро-англійський філософ Л. Вітгенштайн (1995). У праці “Філософські дослідження” він презентує таку теорію мови: мова пов'язана не з об’єктами, а з діяльністю. На підкріплення цієї думки Л. Вітгенштайн уводить у науковий обіг термін “мовна гра”. “Я називатиму також “мовною грою” сукупність 
мови й діяльності” (Вітгенштайн, 1995, с. 95). Під грою він розуміє не те, чим займаються люди, аби розважитися. Мовна гра у розумінні Л. Вітгенштайна - це моделі використання мови та її функцій. Філософ стверджує, що будь-яке слово чи речення може бути вжитим безліччю способів, які ми обираємо відповідно до нашої “форми життя”. Він описує гіпотетичну конструкцію мовної гри як спосіб, завдяки якому суспільство вчиться говорити й діяти.

Згодом саме таке тлумачення мовної гри укорінилося серед мовознавців. На сьогодні термін "мовна гра" позначає всі можливі ситуації, коли мовець вільно поводиться з формою мовлення. Так званий “експромт" під час вираження думок простежується чи не на всіх мовних рівнях. У межах фонетичного рівня мовна гра реалізується за допомогою зміни швидкості й ритміки мовлення, акцентуації й римованої співзвучності слів, вимови з акцентом, зміни тембру тощо. Граматичний рівень обмежується переважно оказіональними граматичними формами або граматичною варіативністю. На лексичному рівні головна роль належить полісемічним і омонімічним одиницям, чиї нестандартні поєднання викликають у слухача зацікавленість до слів мовця. Фразеологічний рівень також репрезентує мовну гру у вигляді словосполучень, побудованих з використанням багатозначності слів, усіх видів омонімії та парономазії.

Проте у багатьох термінологічних словниках термін “мовна гра" все ж відсутній. Це зумовлено тим, що наведене поняття часто ототожнюють 3 поняттям “гри слів". Насправді ж останній термін $€$ набагато вужчим і виконує роль підвиду мовної гри. Гра слів - літературний прийом та водночас форма дотепу, в якому слова-компоненти вживаються з метою досягнення задуманого мовцем ефекту або просто покликані розважити (Ask Difference, 2018).

Прийом гри слів зазвичай реалізується за допомогою використання багатозначності, омонімії й паронімії та діє на різних мовних рівнях. Його можна віднести до поля ідіоматичності мовлення як психолінгвістичного та лінгвістичного феномену своєрідності світосприймання і вербального менталітету нації, що виражається в закріпленні в мовленнєвому узусі певної мови синкретичних мовленнєвих одиниць різного ступеня стійкості, які є специфічними для певної мовленнєвої спільноти в плані структури, семантики й особливостей вживання та викликають труднощі при доборі повних еквівалентів з інших мов (Подосиннікова, 2002).

Нерідко натомість терміна “гра слів" вживається термін “каламбур”. Чимало довідників й електронних джерел подають їх як дві тотожні назви на позначення одного й того самого явища. Насправді ж каламбур є набагато вужчим поняттям. Каламбур - стилістичний прийом, що покликаний викликати у реципієнта передбачуваний гумористичний ефект. Досягнення такого ефекту відбувається внаслідок навмисного використання омофонічних й омографічних одиниць, метонімічної чи образної мови (Ask Difference, 2018).

Тож попри те, що поняття “мовна гра”, “гра слів” і “каламбур” у межах сучасної лінгвістики часто трактують як синонімічні, посилаючись на їхні однакові засоби творення та функції в мові, вони все ж мають певні відмінності у значеннях, зокрема в методиці навчання.

Повертаючись до теорії когнітивного розвитку Ж. Піаже та його ідеї про гру як місток до пізнання навколишнього світу, можна спроеціювати природний розвиток людини з віком на процес формування мовленнєвих навичок під час вивчення іноземної мови. Мозок опановує нову / іноземну мову подібно до того, як дитина вчиться говорити рідною. I якщо у дитинстві саме ігри сприяють кращому розвитку когнітивних здібностей людини, то ефект ігор у процесі навчання буде аналогічним - задіяні в ході ігор пам'ять, логіка, уява, сприйняття здатні забезпечити результативніше вивчення іноземної мови, оскільки воно не є примусовим, але підсвідомим. Звичайно в такому разі йдеться не про звичайні ігри, а про мовні ігри.

Грунтуючись на аналізі вищезазначених споріднених із грою понять (“мовна гра", "гра слів", “каламбур”), найдоцільніше звернути увагу на гру слів, оскільки саме це явище має найширшу функціональність. Окрім функції творення комічного, яку загальна стилістика 
визначає, як головну та єдину, на інших функціональних рівнях гра слів реалізує широкий спектр невказаних функцій. Так, наприклад, лише в рекламних текстах цьому явищу притаманна значна кількість функцій: 1) збудження уваги; 2) збудження інтересу; 3) підвищення експресивності повідомлення; 4) підвищення симпатії; 5) розширення кола реципієнтів; 6) економії засобів вираження; 7) інтенсифікації пам'яті; 8) унаочнення аргументації; 9) ідентифікації (Nord, 1999). Відповідно кожен наступний розглянутий функціональний рівень додаватиме грі слів нові, непритаманні іншим сферам, функції. Не є винятком сфера навчання іноземних мов, де освітня функція цього явища розгалужується на підфункції залежно від методу впровадження гри слів в освітній процес.

Гра слів $є$ чудовою технологією формування соціолінгвістичної компетентності та розвитку комунікативних здібностей учнів на уроках англійської мови. Когнітивним компонентом $є$ репрезентативно-когнітивні структури, як узагальнено-абстрактний результат набуття комунікативних знань, навичок і вмінь. Когнітивна психологічна структура, як основа комунікативних здібностей, $є$ багаторівневою і складається з фонологічного, граматичного, лексичного й дискурсивного рівнів (Якимчук, 2010).

Проаналізуємо, які існують варіанти впровадження гри слів для розвитку когнітивних і мовленнєвих навичок деяких рівнів.

Фонологічний рівень. Оскільки саме цей рівень містить необхідні ресурси для розпізнавання усіх фонем певної мови, то опрацьовані приклади гри слів мають базуватися на фонетичній подібності, тобто мати в своїй основі омофони (слова з однаковим звучанням, проте різними значеннями). Наприклад, учням зачитується вислів Reading while sunbathing makes you well $\mathrm{red}$, де гра слів реалізується за допомогою омофонів red i read (дієслово “читати" у минулому часі). У такому поєднанні виходить, що читаючи й засмагаючи одночасно, можна стати червоним або ж добре начитаним.

Після озвучення вислову учням пропонується його перекласти, записавши еквівалент рідною мовою, або пояснити, як вони його зрозуміли (рідною чи англійською мовою, залежно від рівня). Скоріше за все, думки розділяться, внаслідок виникне обговорення. 3 точки зору когнітивної психології в цей час відбудеться фонематичний аналіз звукової інформації, що в поєднанні з уявою (ситуація з оу) створить передумови для стійкого запам'ятовування фонем.

Інші приклади явища гри слів, реалізованого завдяки омофонам, для різних рівнів володіння мовою:

I'm close friends with 25 letters of alphabet, I don't know $\boldsymbol{y}$.

The past, the present, and the future walked into a bar. It was tense.

A bicycle cannot stand on its own because it is two-tired (Real Life English, 2013).

Лексичний рівень. У когнітивній структурі мовленнєвих здібностей існує “словник” сховище всіх відомих певній людині слів тієї чи іншої мови. У словнику слова зберігаються в упорядкованій системі. Кожне слово $є$ пов'язаним за змістом з іншими словами. Наприклад, усі слова організовано за понятійними категоріями: живі та неживі істоти, рослини, тварини, прилади, інструменти тощо. Більш широкі категорії включають вужчі. Слова також організовано за належністю до певного часу, місця, за причинно-наслідковими зв'язками, за належністю до певних наук, частин мови тощо (Якимчук, 2010). Лексичний рівень представлений найбільшою кількістю варіантів упровадження явища гри слів у навчання, оскільки саме лексичні одиниці $€$ основою вказаного лінгвістичного явища. На уроках іноземної мови використання гри слів "каламбур" слугує ефективним способом розширення лексичного запасу.

Найпростішим способом застосування гри слів “каламбур" на уроках англійської мови $€$ їх аналіз зі зверненням уваги на те, як саме гра слів реалізується. Каламбури, пропоновані вчителем, можуть бути як короткими висловлюваннями, на кшталт Time flies like an arrow. 
Fruit flies like a banana, де у першому реченні йдеться про швидкоплинність часу, а у другому про комах, які полюбляють банани (Real Life English, 2013); так і короткими історіями, наприклад:

A woman was driving in her car on a narrow road. She was knitting at the same time, so she was driving very slowly.

A man came up from behind and he wanted to pass her. He opened the window and yelled, "Pull over! Pull over!"

The lady yelled back, "No, it's a sweater! (The Internet TESL Journal).

Допомогти учням повністю поринути у світ багатозначних слів можна, запропонувавши їм самостійно створити каламбури. Для цього вчитель добирає речення, що містять щонайменше два полісемічних слова. Наприклад:

Let's talk about rights and lefts.

Time flies when having fun.

How can you stay cool with a fan?

Спочатку вчитель ще раз нагадує учням значення деяких слів, а потім дає кілька хвилин, аби вони самостійно перефразували вислів або дали йому логічне, проте цікаве продовження, користуючись іншими значеннями полісемічних слів. Можливі варіанти каламбурів:

You're right, so I left aбо I left because I have such a right.

Time's fun when you're having flies.

How can you stay cool having fans? - Just turn all of them off (The Internet TESL Journal).

Ускладнити завдання можна, обговорюючи значення слів - учні самі виявляють полісемічні лексичні одиниці.

Іноді в основі каламбурів лежать ідіоми. Звичайно ж складність розуміння такої гри слів підвищується, оскільки ідіоми передбачають гарне володіння мовою та фонові знання культури чи історії країни виучуваної іноземної мови. Проте для учнів старших класів аналіз каламбурів 3 ідіомами є ефективним прийомом, як вивчити усталений вислів, так і обговорити ситуацію. Наприклад: Ben Franklin used to fly his kite in the storm because he got a charge out of it. У цьому випадку гра слів полягає у фразі get a charge out of something, що означає отримувати справжнє задоволення. Комічності надає натяк на факт, що Бен Франклін отримав електричний удар, коли блискавка влучила в його повітряного змія.

Sleeping comes so naturally to me, I could do it with my eyes closed. У такому поєднанні ідіома with your eyes closed (з легкістю) запам'ятовується краще (Lems, 2013).

Чимало ідіом й усталених висловів чи назв в англійській мові побудовано шляхом каламбурного зближення слів. У такому разі дієвим способом є підкріплення прикладів гри слів ілюстраціями, що сприяють запам’ятовуванню (Strolovich, 2019) (див. рис.1).

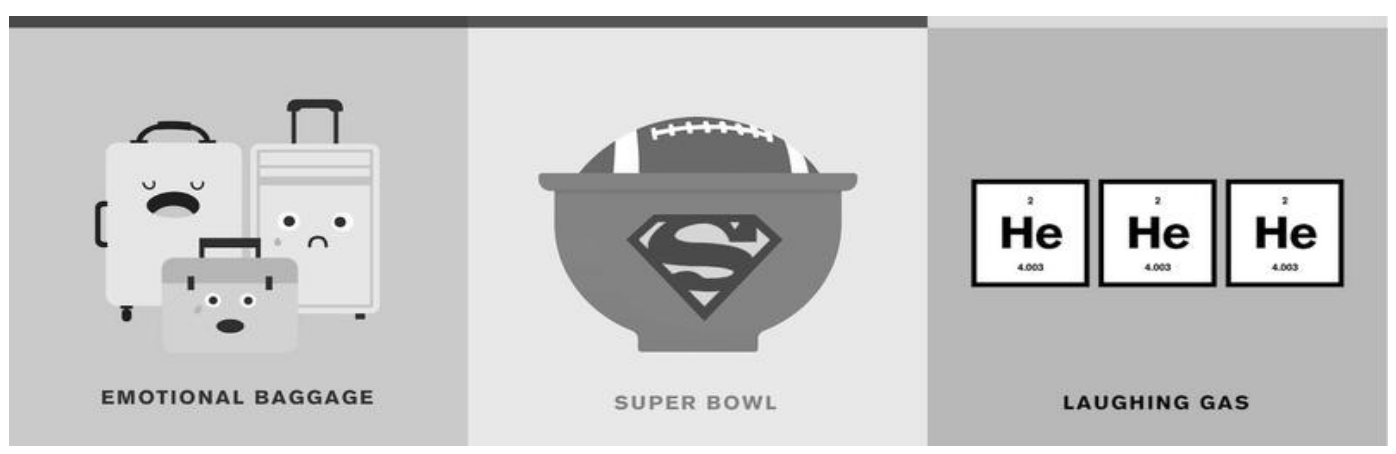

Рис.1 Ілюстрації прикладів ідіом чи усталених висловів 
Ще одним прийомом розширити лексичний запас учнів є відгадування загадок. В англійській мові в основі багатьох загадок лежить гра слів, створена на основі як омофонів, так і полісемічних слів. Зрозуміла й цікава для учнів діяльність активно розширює їхній словниковий запас. Приклади загадок з грою слів:

What's black and white and red all over the world? - A newspaper. Гра слів на основі вищезгаданих омофонів read та red.

What weather do mice most dislike? - When it's raining cats and dogs. Каламбур утворено шляхом використання ідіоми rain cats and dogs.

When does the baker follow his trade? - Whenever he kneads the dough. Загадка для учнів 3 високим рівнем володіння мовою, оскільки гра слів реалізується за допомогою як омофонів knead (місити) та пееd (потребувати), так і полісемічного слова dough (micmo та розм. гроші).

What is the best fruit for studying history? - Dates. Гру слів створює полісемія слова dates (дати; фініки) (Gan, 2015).

У межах виучуваного матеріалу вчитель може створити добірку каламбурів певної тематики. Наприклад, у межах теми “Шкільне життя” обираються каламбури, які стосуються різних предметів:

English: English teachers are always write!

Science: Once I told a chemistry joke. There was no reaction.

Math: Not all math puns are horrible. Only sum.

History: History. History. Did I just rewrite history? (Faculty Loungers, 2013).

Принагідно зазначимо, що з метою розвитку когнітивних і мовленнєвих навичок учнів ми вбачаємо методичну доцільність упровадження в освітній процес матеріалів британського імпровізійного шоу “Whose line is it anyway?”. Його епізоди є автентичним аудіовізуальним матеріалом і взірцем використання гри слів “каламбур” у непідготовленому мовленні. Перегляд відео й аналіз реплік шоу сприяє розвитку когнітивних навичок і формуванню в учнів соціокультурної іншомовної компетентності. На основі окремих тематичних блоків (“Let's Make a Date”, “Weird Newscasters”, “Props”) можуть бути змодельовані ігрові форми вправ, зокрема рольові ігри задля розвитку мовленнєвих навичок (Гончарові \& Красуля, 2019).

Висновки і перспективи подальших розвідок. Формування в учнів іншомовної компетентності неможливе без розвитку когнітивних (пізнавальних) навичок. Згідно 3 концепціями теорії когнітивного розвитку Ж. Піаже становлення пізнавальних здібностей людини, до яких належать сприйняття, пам'ять, логіка й уява, вміння вирішувати проблеми тощо, найкраще відбувається в процесі ігрової діяльності. Оскільки стадії формування пізнавальних навичок людини в ході життя умовно відповідають етапам вивчення іноземної мови, доходимо висновку, що ігри є важливим компонентом розвитку соціолінгвістичної іншомовної компетентності.

Поняття "гри” у парадигмі лінгвістики та методики навчання іноземних мов має певні функціональні відмінності. У ході дослідження визначено, що найширшим поняттям є мовна гра, явище, що знаходить прояв у будь-яких навмисних порушеннях загальноприйнятих норм літературної мови. Гра слів $\epsilon$ різновидом мовної гри, в межах якого слова-компоненти вживаються з метою досягнення задуманого мовцем ефекту або покликані розважити. Найвужчим поняттям є каламбур, функція якого обмежується створенням гумористичного ефекту.

Виявлено, що в межах навчання / вивчення англійської мови доцільно впроваджувати такий засіб, як гра слів “каламбур”. Аналіз, обговорення, самостійне створення каламбурів сприяють розширенню лексичного запасу учнів з різним рівнем володіння мовою. Опрацювання прикладів аналізованого лексичного явища стимулює уяву учнів, формує їхнє логічне мислення й активізує механізми запам'ятовування. Окрім того, розгляд прикладів гри слів на основі омофонів розвиває когнітивні здібності для розпізнавання всіх фонем іноземної мови. 
Таким чином, проаналізувавши прийоми впровадження гри слів “каламбур” на уроках англійської мови, ми рекомендуємо розглянутий стилістичний прийом як дієвий спосіб розвитку когнітивних здібностей учнів і формування соціолінгвістичної компетентності. Перспективи подальших досліджень вбачаємо в укладанні методичних рекомендацій щодо інтегрованого формування в учнів мовної й соціолінгвістичної компетентностей на основі проаналізованого явища, зокрема на матеріалі британського імпровізійного шоу “Whose line is it anyway?".

\section{ЛIТЕРАТУРА}

Бігич, О. Б., Бориско, Н. Ф., Борецька, Г. Е., Гапонова, С. В., Майєр, Н. В., Ніколаєва, С. Ю., ... Шукліна, С. І. (2013). Методика навчання іноземних мов і культур: теорія і практика. Київ, Україна: Ленвіт.

Вітгенштайн, Л. (1995). Tractatus Logico-Philosophicus; Філософські дослідження. Київ: Основи.

Вовк, О. І. (2013). Комунікативно-когнітивна компетентність майбутніх філологів: нова парадигма сучасної освіти. Черкаси: Видавець Чабаненко Ю.А.

Гончарова, О. В. \& Красуля, А. В. (2019). Рольова гра як метод формування мовленнєвих навичок студентів. В Інноваиії та традииї̈ у мовній підготовиі іноземних студентів: тези доповідей міжнародного науково-практичного семінару. Матеріали міжнародного науковопрактичного семінару 6 грудня 2019 року (сс. 91-93). Харків: Видавництво Іванченка I. С.

Гудкова, Н. М. (2015). Сутність комунікативно-когнітивного підходу до викладання іноземної мови фахового спрямування у вищому навчальному закладі. Наукові записки Наиіонального університету “Острозька академія". Серія: Філологічна, 54, 21-23.

Карпова, В. М. (1995). Формування комунікативно-навчаючих умінь проведення буквених ігор на позакласному занятті з іноземної мови (факультет англійської мови, початковий етап) (Автореферат кандидатської дисертації). Київський лінгвістичний університет, Київ, Україна.

Ніколаєва, С. Ю. (2010). Зміст навчання іноземних мов і культур у середніх навчальних закладах. Іноземні мови, 3, 3-10.

Пиаже, Ж. (1967). Избранные психологические произведения. Москва: Просвещение.

Подосиннікова, Г. І. (2002). Навчання студентів-філологів ідіоматичних предикативних конструкцій англійського розмовного мовлення на матеріалі автентичних художніх текстів. (Автореферат кандидатської дисертації). Київський національний лінгвістичний університет, Київ, Україна.

Якимчук, Ю. В. (2010). Розвиток когнітивного компонента комунікативних здібностей у студентів вищих навчальних закладів. Вісник Національної академії Державної прикордонної служби України, 4. Взято з http://nbuv.gov.ua/UJRN/Vnadps_2010_4_26

Ask Difference. (2018, May 12). Wordplay vs. Pun - What's the difference? Retrieved from https://www.askdifference.com/wordplay-vs-pun/

Faculty Loungers. (2018, August 11). 10 Funny Teacher Puns Per Subjcet (History, English, Math, Science). Retrieved from https://facultyloungers.com/blogs/teacher-memes/teacher-puns-10per-subject

Gan, X. (2015). A study of the humor aspect of English puns: views from the Relevance Theory. Theory and Practice in Language Studies, 5(6), 1211-1215.

Lems, K. (2013). Laughing All the Way: Teaching English Using Puns. English Teaching Forum, $51(1), 26-33$.

Nord, O. (1999). Die Funktion von Wortspielen in Werbeanzeigen. Untersuchungen zur Werbewirksamkeit von Wortspielen anhand eines Zeitschriftenkorpus. Heidelberg, Univ. Magisterarb. Verfügbar unter http://www.ono-line.de/wortspiel/

Real Life English. (2013, July 12). Fun English: Increase Your Vocabulary with Puns (Jokes with Double Meanings) Retrieved from https://reallifeglobal.com/fun-english-vocabulary-puns/

Strolovich, D. (2019, April 5). Philosophy Talk: More Than Pun and Games? Retrieved from https://www.kalw.org/post/philosophy-talk-more-pun-and-games\#stream/0 
The Internet TESL Journal. Jokes in English for the ESL / EFL Classroom. Retrieved from http://iteslj.org/c/jokes-puns.html\#kelly 1

\section{REFERENCES}

Bihych, O. B., Borysko, N. F., Borets'ka, H. E., Haponova, S. V., Majier, N. V., Nikolaieva, S. Yu., ... Shuklina, S. I. (2013). Metodyka navchannia inozemnykh mov i kul'tur: teoriia i praktyka. Kyiv, Ukraina: Lenvit.

Vithenshtajn, L. (1995). Tractatus Logico-Philosophicus; Filosofs'ki doslidzhennia. Kyiv: Osnovy.

Vovk, O. I. (2013). Komunikatyvno-kohnityvna kompetentnist' majbutnikh filolohiv: nova paradyhma suchasnoi osvity. Cherkasy: Vydavets' Chabanenko Yu.A.

Honcharova, O. V. \& Krasulia, A. V. (2019). Rol'ova hra iak metod formuvannia movlennievykh navychok studentiv. V Innovatsii ta tradytsii u movnij pidhotovtsi inozemnykh studentiv: tezy dopovidej mizhnarodnoho naukovo-praktychnoho seminaru. Materialy mizhnarodnoho naukovopraktychnoho seminaru 6 hrudnia 2019 roku (ss. 91-93). Kharkiv: Vydavnytstvo Ivanchenka I. S.

Hudkova, N. M. (2015). Sutnist' komunikatyvno-kohnityvnoho pidkhodu do vykladannia inozemnoi movy fakhovoho spriamuvannia u vyschomu navchal'nomu zakladi. Naukovi zapysky Natsional'noho universytetu "Ostroz'ka akademiia". Seriia: Filolohichna, 54, 21-23.

Karpova, V. M. (1995). Formuvannia komunikatyvno-navchaiuchykh umin' provedennia bukvenykh ihor na pozaklasnomu zaniatti z inozemnoi movy (fakul'tet anhlijs'koi movy, pochatkovyj etap) (Avtoreferat kandydats'koi dysertatsii). Kyivs'kyj linhvistychnyj universytet, Kyiv, Ukraina.

Nikolaieva, S. Yu. (2010). Zmist navchannia inozemnykh mov i kul'tur u serednikh navchal'nykh zakladakh. Inozemni movy, 3, 3-10.

Piazhe, Zh. (1967). Izbrannye psihologicheskie proizvedenija. Moskva: Prosveshhenie.

Podosynnikova, H. I. (2002). Navchannia studentiv-filolohiv idiomatychnykh predykatyvnykh konstruktsij anhlijs'koho rozmovnoho movlennia na materiali avtentychnykh khudozhnikh tekstiv. (Avtoreferat kandydats'koi dysertatsii). Kyivs'kyj natsional'nyj linhvistychnyj universytet, Kyiv, Ukraina.

Yakymchuk, Yu. V. (2010). Rozvytok kohnityvnoho komponenta komunikatyvnykh zdibnostej u studentiv vyschykh navchal'nykh zakladiv. Visnyk Natsional'noi akademii Derzhavnoi prykordonnoi sluzhby Ukrainy, 4. Vziato z http://nbuv.gov.ua/UJRN/Vnadps_2010_4_26

Ask Difference. (2018, May 12). Wordplay vs. Pun - What's the difference? Retrieved from https://www.askdifference.com/wordplay-vs-pun/

Faculty Loungers. (2018, August 11). 10 Funny Teacher Puns Per Subjcet (History, English, Math, Science). Retrieved from https://facultyloungers.com/blogs/teacher-memes/teacher-puns-10per-subject

Gan, X. (2015). A study of the humor aspect of English puns: views from the Relevance Theory. Theory and Practice in Language Studies, 5(6), 1211-1215.

Lems, K. (2013). Laughing All the Way: Teaching English Using Puns. English Teaching Forum, 51(1), 26-33.

Nord, O. (1999). Die Funktion von Wortspielen in Werbeanzeigen. Untersuchungen zur Werbewirksamkeit von Wortspielen anhand eines Zeitschriftenkorpus. Heidelberg, Univ. Magisterarb. Verfügbar unter http://www.ono-line.de/wortspiel/

RealLife English. (2013, July 12). Fun English: Increase Your Vocabulary with Puns (Jokes with Double Meanings) Retrieved from: https://reallifeglobal.com/fun-english-vocabulary-puns/

Strolovich, D. (2019, April 5). Philosophy Talk: More Than Pun and Games? Retrieved from https://www.kalw.org/ post/philosophy-talk-more-pun-and-games\#stream/0

The Internet TESL Journal. Jokes in English for the ESL / EFL Classroom. Retrieved from http://iteslj.org/ c/jokes-puns.html\#kelly1 